\title{
Global Brands in the Digital Era ${ }^{1}$
}

\section{Глобални брендови у ери дигитализације}

Tomislav Sudarevic*

University of Novi Sad, Faculty of Economics in Subotica, Subotica

Drazen Maric $^{* *}$

University of Novi Sad, Faculty of Economics in Subotica, Subotica

\begin{abstract}
One of the most prominent words today definitely is digital. It is all around us. From products that are digital to a highest possible degree, to the digital management practices in operating different businesses, down to discussions on benefits and shortcomings of the digital society. At the same time, the world is becoming increasingly global, which is boosting digitization to a large extent. Related to different aspects of globalization, the paper is focused on researching possibilities that digitization is bringing within itself, which can be productive in a process of making (and empowering) global brands. Sharply increasing the amount of information that is available to global consumers today through digital touchpoints (Facebook, Twitter, or product-evaluation platforms), gives great great opportunities for products/services to become globally branded. At the same time, for globally oriented companies it poses a threat of a free interpretation of intended information value about their brands.
\end{abstract}

Keywords: globalization, global brands, digitization, consumer decision journey.

Сажетак: Једна од најчешће коришћених речи у савременом свету јесте: дигитално. Почевши од производа који су дигитални у највећој могућој мери, преко примене дигиталних метода пословања у различитим областима, па до бројних дискусија о предностима и недостацима дигиталног друштва. Истовремено, свет све већој мери постаје глобалан, што у великој мери даје ветар у леђа дигитализацији. Разматрајући различите аспекте глобализације, фокус је у раду усмерен ка установљавању могућности које дигитализација носи у себи, а које могу бити продуктивно употребљене у процесу креирања (или оснаживања) глобалних брендова. Брзорастући број информација које су доступне потрошачима глобалних брендова посредством дигиталних „тачака додира“ (touchpoints), попут Facebook-a, Twitter-a и других платформи за оцену производа, пружа велике могућности за глобално брендирање производа/услуга. У исто време то представља и опасност за глобално оријентисане компаније, с обзиром на могућност слободне интерпретације свега онога што оне желе да представе као вредност свог бренда.

Кључне речи: глобализација, глобални бренд, дигитализација, потрошачки пут одлучивања.

\section{Introduction}

Amongst different causes if only one is to be chosen, which has had a strong and constant impact on the development of mankind, it is connectivity. Throughout history of mankind it has been proven time after time that those nations that were more successful in making connections with other people around the globe made faster progress than closed societies. For that reason it is logical that today we are living in a

\footnotetext{
${ }^{1}$ The authors gratefully acknowledge financial support from the Ministry of Education, Science and Technological Development of the Republic of Serbia (Project III 46005).

* $\square$ tsudar@ef.uns.ac.rs

** $\bowtie$ drdrazen75@yahoo.com
} 
global world where people are connected to a large extent. Modern information technology enables transfer of information to literally every corner of the world. Logistical systems are in the service of information flow thus enabling worldwide delivery of globally available products and services. In a word, we are living in a global era with countless connections between people, companies and governments.

The very concept of globalization has different aspects to be taken in consideration. Thus, Albrow (1990) and Held et al. (1999) in their definitions of globalization stress that it is a process (or set of processes) related to integration of different nations in form of networks into one global society. International Monetary Fund (IMF) is mainly focused on integration of different national economies through movements of goods, services and capital. Stieglitz (2003) also regards globalization predominantly as a means of destroying artificially created frontiers for free movement of capital, people, goods and services by decreasing costs of transportation and communication. Common to all of these definitions (and others as well) is the idea of pervasion of the globalization process in all pores of the social tissue.

Business practice is proving it in the most obvious example of ICT sector (information and communication technologies). As Desruelle and Stancik (2014) claim in their research: "ICT value chains span the globe; ICT firms select on a global basis the best locations, not only for ICT production, but also for ICT R\&D and innovation." In the conditions of global competition, "creative economy" arises (Kyng Sung, 2015). Opposed to 20th century industrial economic ecosystem (that was based on labour and capital), in the new one value creation is in the form of innovative technology and creative ideas on a global level. Basic feature of those new, innovative technologies is that they enable extremely rapid communication. Thus all of us have the sensation of living in a global state with national economies "evolving under the influence of globalization generated by globalization” (Mihai \& Titan, 2014).

However, when we are discussing the importance and future of the globalization process it is possible to recognize three different groups of opinion on this (Held at al., 1999). The first one, the so-called "hyper globalists" advocate the opinion that it is a process of creating a unified, global market where global competitiveness will be prerequisite for development. Through creating transnational networks of production, trade and finance, all economic activities will become denationalized. National governments are already confronted with growing power of regional and international institutions like EU, STO, IMF and others, they say. Therefore, globalization is, most of all, an economic phenomenon and an unstoppable force towards world market without frontiers, they conclude.

At the other end of this scale are those who call themselves "global sceptics". Their view is that globalization is just a myth, most of all in regard to the idea of globally integrated world market. They object to hyper globalists' underestimation of the power of national governments, calling them politically naive. National 
governments are not victims of globalization but active players in that process. Integrative processes of unification of national states into blocks on regional base (EU, NAFTA ...) are showing that idea of one world market will never be achievable, they claim.

Proponents of the third school on globalization are the so-called "transformationalists". They agree that globalization has a key importance for social, political and economic transformations under which modern society and world order is in a process of reshaping. They see globalization in the light of long-term perspective on mixing societies, economies, and institutions thus creating new world order. However, they oppose the idea of creating world without frontiers. As a key argument for it they use the case of EU as an example. Although the strength and importance of institutions that all member states have jointly created have to be appreciated, there will always be a need for national governments to take active role in regulating part of the joint market that is under their jurisdiction.

Whichever scenario on outcomes of globalization in times to come is to be accepted, the most important fact that has to be kept in mind is that it will be achieved in a new environment that best can be described in one word - digital. Digitization as a process is already in progress and will prevail in future making us talking about era of digitization as a common term.

\section{Era of digitization}

The concept of digitization at the company level can be seen from different standpoints. In its most elementary scope of understanding, it refers to technology that is digital with all of its benefits that its application is bringing to the company. At a higher level of its comprehension we are talking about digitization as a new way of company engagement with customers. And finally, as an overwhelming concept it can be seen as a "way of doing business" (Dorner \& Edelman, 2015) that comprises: creating value at new frontiers, creating value in core businesses and building foundational capabilities that support the entire structure. Creation value at new frontiers can be directed towards business inside the car industry that is present in the concept of self-navigation car (connected to the outside world) is internal challenge for car producers, while for some electronic device producers can be external challenge in stretching their activities. Creating value in core businesses is in fact rethinking how to use digital technology for serving the customers better. Key words in that process are design and delivery of the best possible experience. If properly done, for its consequence it will have product or service loyalty that will be constantly upgraded based on inputs from the customers. For all of the previously said, company has to build foundational capabilities to implement digital benefits in operating its business by building digital networks that connect devices, objects, and people. It is not to be forgotten that a new mind-set with flattened hierarchy and free flow of new initiatives is of crucial importance for this. 
Obviously, digitization of company performances is a demanding and long lasting process that is unevenly present in different types of companies. Comprehensive research done by McKinsey's authors Bughin, LaBerge and Mellbye (2017) proves this in the best possible way. As it can be seen from Figure 1, level of penetration of digitization differs substantially between the industries.

Figure 1. Perception of digital penetration by industry, $1 \%$ of respondents

Average across all industries $=37 \%$

Fully

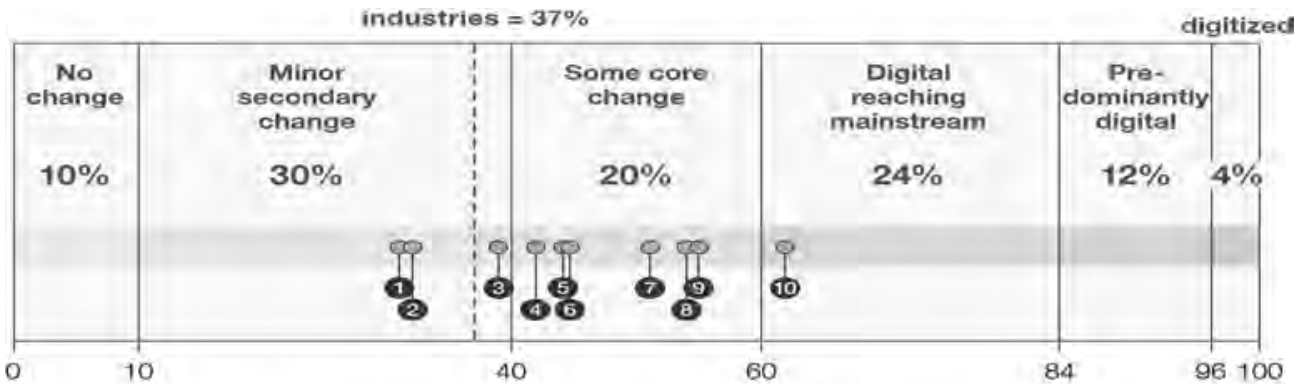

Selected industries ${ }^{2}$

(1) Consumer packaged goods (31\%)

(2) Automotive and assembly $(32 \%)$

6 Travel, transport, and logistics $(44 \%)$

(3) Financial services (39\%)

(2) Healthcare systerns and services (51\%)

(4) Professional services (42\%)

(8) High tech (54\%)

(6) Telecom (44\%)

(9) Retail $(55 \%)$

(10) Media and entertainment (62\%)

The data reflect average of respondents' ratings on degree of change in the past three years within each industry across 5 dimensions (products, marketing and distribution, processes, supply chains, and new entrants at the ecosystem level).

2 For consumer packaged goods, $\mathrm{n}=85$; automotive and assembly, $\mathrm{n}=112$; financial services, $\mathrm{n}=310$; professional services, $\mathrm{n}=307$; telecom, $\mathrm{n}=55$; travel, transport, and logistics, $\mathrm{n}=103$; healthcare systems and services, $\mathrm{n}=78$; high tech, $\mathrm{n}=348$; retail, $\mathrm{n}=89$; and media and entertainment, $\mathrm{n}=86$.

\section{Source: Bughin, LaBerge and Mellbye, McKinsey Quarterly, 2017}

The fact that average rate of digitization penetration across all industries is just $37 \%$ tells that a lots of ground in this particular way of doing business just has to be won. At the same time, it is no surprise that media and entertainment industry is leading in application of digital strategies $(62 \%)$ due to its fateful relation to consumers that are becoming increasingly digital on a daily basis.

Amongst many interesting findings of the above mentioned research, for the purpose of this paper, the answer to the question of focusing digital strategies has special importance (Figure 2). 
Figure 2. Where are companies focusing their forward-looking digital strategies?

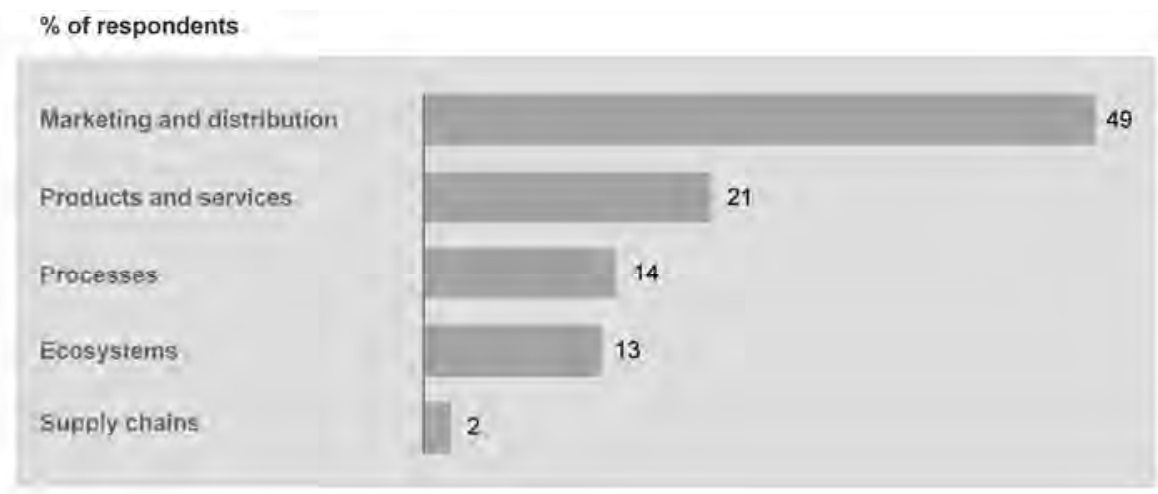

Source: Bughin, LaBerge and Mellbye, McKinsey Quarterly, 2017

It can be seen that distribution channels and marketing are in focus of digital strategies for 49 percent of the surveyed companies. Such a high percentage in this category of activities is not surprising having in mind the substantial impact that digitization has already manifested on customer interactions, especially when global brands are in case. In a sense, it is "a must" in order to stay in the game.

\section{Global brands}

However, it might seem that it is easy to understand the concept of global brands; it is a demanding task in which so many authors gave their contribution. Some of them (Maljers, 1992; Özsomer \& Prussia, 2000; Yip, 1995) took the supply side perspective talking about global brands as company's tool to exploit good products and ideas at a large number of markets. Other authors (e.g., Alden, Steenkamp, \& Batra, 1999; Holt, Quelch, \& Taylor, 2004) are approaching the concept of global brands from the demand side i.e. from a unique perceived image or "myth" it has in the mind of the consumers worldwide. It is actually due to global positioning in mind of the consumers that global brands are developing similar aspirations, tastes and needs all over the world market (Özsomer \& Simonin, 2004; Steenkamp \& Ter Hofstede, 2002; Steenkamp \& de Jong, 2010).

For the purpose of this paper, a synthesized definition by group of authors (Özsomer et al., 2012) will be used: "Global brands are those that have global awareness, availability, acceptance, and desirability and are often found under the same name with consistent positioning, image, personality, look, and feel in major markets enabled by standardized and centrally coordinated marketing strategies and programs."

In the first part of the definition of global brands, concepts of awareness, 
acceptance and desirability are emphasized, for which implementation of digital assets of the companies have increasing importance today. It is, actually, in the first stage of the consumer decision journey that digital communication between company and consumers is of essential importance for global brands (see Figure 3.).

Figure 3. The consumer decision journey

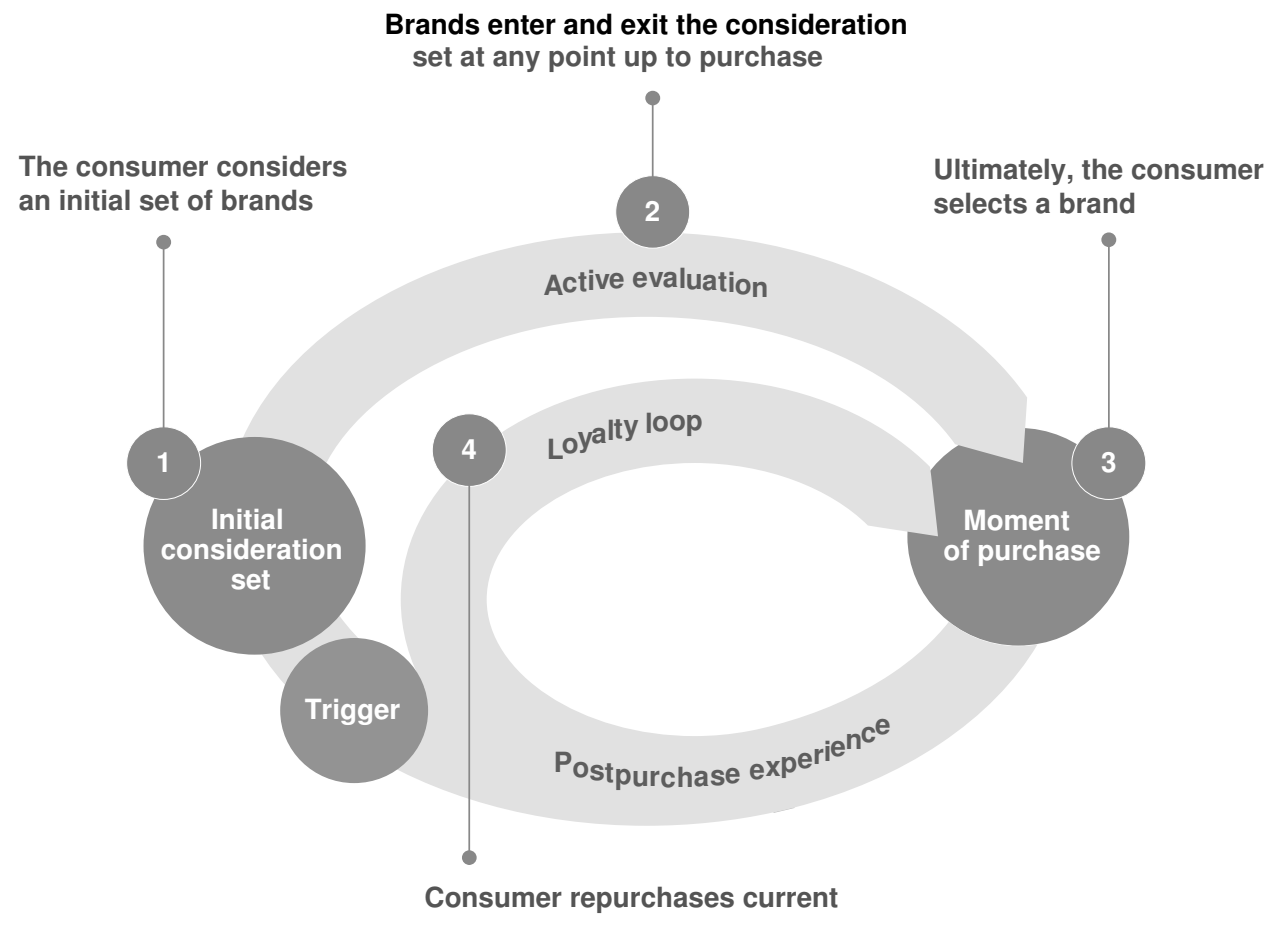

brand without shopping for others

Source: Court, Elzinga and Perrey, McKinsey Quarterly, 2017

We are all witnesses of fast accelerated growth in tools that consumers are using in a process of researching and purchasing products in online mode. Technical aspects of digitization that are present in a vast number of mobile shopping applications enables all producers, not just for a global brands once, to influence consumers opinion in an early stages of decision making. Through this application consumers are in a situation to easily compare product specifications amongst different brands, their prices, availability etc. Furthermore, the role of social networks (Facebook, LinkedIn and Twitter, to name just few of the most prominent one) makes it easy for every consumer to know in detail what their friends (peers) are buying and how they feel about every brand that they have some experience with. Loyalty as it used to be before, based on the fact that consumers do not know about any better, or to be more precise - 
based on a lack of information about better offer, is a matter of past. Perhaps the best illustration of this statement could be found in research done within McKinsey's customer decision journey database, which covers more than 125,000 consumers, shopping for more than 350 brands (Court, Elzinga and Perrey, 2017). The results are worrying for producers of most of the 30 researched categories of products. Only in the case of 3 of them (mobile operators, auto insurance and investments) customers were loyalty driven i.e. repeated the brand choice in next purchase instead of shopping around. On the other hand, strong shopping tendencies are present in the other 27 categories of products (amongst them: shoe retail, cosmetics, personal computers, financial services, autos, laptops and women's clothing).

For this reason (lack of loyalty) it is of highest importance for global brand producers to invest their resources in research on what triggers consumers to shop, at a moment just before making initial considerations for their future purchase. For brands that are in a process of becoming global, this is crucial. In the above stated research, it was proved that the brands that were in the initial consideration set, had more than twice as high probability to be purchased compared to brands that were considered in later stages of the decision journey. Amongst the consumers who switched brands in their next purchase, it is a significant 69 percent of them who did it based on information they gained in the initial consideration set (Court, Elzinga and Perrey, 2017).

Having in mind the fact that most of the consumers in their decision journey are showing strong shopping tendencies (resulting in switching the brands), the question arises about investing marketing dollars, predominantly in loyalty programs. This does not mean that investing in post-purchase experience of the loyal consumers should be totally abandoned. It is only a matter of proportion that in times to come will have to be in favour of innovative programs.

It is not enough for a global brand that consumers in consideration phase are aware of its name only. They have to know more about its unique benefits and value that consumers are buying together with that name. In previous times this would be, in most of the cases, done by using aggressive television advertising. Today, a lot of other digital sources are in a game for the same task to do, and that is to switch consumers that have no experience with a particular brand to buy it or get back consumers that for some reason moved to competitor's brand. The activity that is needed for this is called resegmentation of the consumers. When Disney moved to vacation-cruise business he made resegmentation of the consumers in order to explore why they do not use more of this type of leisure programs. Beside the high costs, it was the nature of the cruising experience that consumers had preconceived notions. Knowing that, Disney made a great use of its already established positive image in entertainment industry and positioned its brand well in minds of the consumers as a unique experience that they will get in vacation-cruise with their ships. 
Necessity for making innovative programs, in order to make brand highly positioned in the mind of the consumers, already in a consideration phase of decision journey, was proven even in hard economic conditions for doing the business. During the recession in 2008, most of the car producers were using short term sales incentives. However, global brand in auto industry Hyundai, approach differently by giving consumers something more valuable than reduction in price. In time of economic instability major concern of potential buyers of the cars was - will they keep the current job and constant earnings to make regular instalment payments for the car they bought? And this is exactly what Hyundai brand did. They promised the buyers of their cars that in case of losing their job they could return the car to the auto dealer where they bought it with no financial obligations further on. Having promotion of this innovative marketing program through digital media to the consumers, who put Hyundai brand in their minds at a phase of initial consideration, they succeeded in being one of the rare companies that had a growth in a difficult time when the complete auto industry was in serious problems.

Digital means of communication have that difficult task to present a global brand in its best light and thus keep competitors brand out of picture during next stage of active evaluation, all up to the moment of purchase.

Loyalty loop as a criterion that distinguishes successful global brands from other brands is based on positive post purchase experience of the consumers as well. As they had a great importance at the beginning of the process, here again social media are playing a vital role for the future of the global brands. Positive post purchase experience of one consumer that is not shared with others is unexploited opportunity for making more of a particular brand market share for itself, which is hard, if not even impossible to compensate.

When speaking about the role of social media in global brand positioning and its expansion on new markets we are exclusively thinking about (and hoping for) only positive aspects of its use. However, a certain threat in the form of a free interpretation of the intended information value about their brands through social media is always present for globally oriented companies.

\section{Conclusion}

Global brands are all around us. They are the easiest visible effect of process of globalization that has so many different facets in its manifestation. Parallel with process of globalization that is taking place, modern societies are confronted with challenges that digitization is bringing within itself. Best described as a "new way of doing things", digitization is an unstoppable process with great potential for fostering globalization and global brands as its precious outcome. Experiences of different companies are showing that the role of digital assets in approaching consumers on time in its "decision journey", i.e. in triggering point, is of great importance for global 
brands' destiny. Through social media and mobile applications, positioning of global brands in minds of consumers is a must - not just an option any more.

\section{Literature}

Desruelle, P., Stančík, J. (2014). Characterizing and comparing the evolution of the major global economies in information and communication technologies. Telecommunications Policy, 38(8-9), pp. 812-826.

Kyung Sung, T. (2015). The creative economy in global competition. Technological Forecasting \& Social Change, 96, pp. 89-91.

Mihai, M., Titan, E. (2014). Education and innovation in the context of economies globalization. Procedia Economics and Finance, 15, pp. 1042 - 1046.

Albrow, M., King, E. (1990). Globalization, Knowledge, Society. Sage Publications, Washington, D.C.

Held, D., McGrew, A., Goldblatt, D., Erraton, J. (1999). Global transformations: Politics, Economics and Culture. Stanford University Press, Stanford

Stiglitz, J. (2003). Globalization and its Discontents. W.W. Norton, New York

Dorner, K., Edelman, D. (2015). What digital really means. McKinsey Quarterly. Downloaded October 8, 2017 from https://www.mckinsey.com/industries/hightech/our-insights/what-digital-really-means.

Bughin, J. LaBerge, L., Mellbye A. (2017). The case for digital reinvention. McKinsey Quarterly. Downloaded October 8, 2017 from https://www.mckinsey.com/businessfunctions/digital-mckinsey/our-insights/the-case-for-digital-reinvention.

Maljers, A. (1992). Inside Unilever: The evolving transnational company. Harvard Business Review. Downloaded October 10, 2017 from https://hbr.org/1992/09/insideunilever-the-evolving-transnational-company?autocomplete $=$ true

Özsomer, A., Prussia, E. (2000). Competing perspectives in international marketing strategy: Contingency and process models. Journal of International Marketing, 8(1), pp. 27-50.

Yip, S. (1995). Total global strategy. Prentice-Hall, New Jersey.

Alden, L., Steenkamp, M., Batra, R. (1999). Brand positioning through advertising in Asia, North America, and Europe. Journal of Marketing, 63, pp. 75-87.

Holt, B., Quelch, A., Taylor, L. (2004). How global brands compete. Harvard Business Review, Downloaded October 10, 2017 from ttps://hbr.org/2004/09/how-globalbrands-compete?autocomplete $=$ true 
Özsomer, A., Simonin, L. (2004). Marketing program standardization: A cross-country exploration. International Journal of Research in Marketing, 21(4), pp. 397-419.

Steenkamp, M., ter Hofstede, F. (2002). International market segmentation: Issues and perspectives. International Journal of Research in Marketing, 19(3), pp. 185-213.

Steenkamp, M., de Jong, G. (2010). A global investigation into the constellation of consumer attitudes toward global and local products. Journal of Marketing, 74(6), pp. $18-40$.

Özsomer, A., Batra R., Chattopadhyay A., ter Hofstede, F. (2012). A global brand management roadmap. International Journal of Research in Marketing, 29, pp. 1-4.

Court, D., Elzinga, D., Finneman, B., Perrey J. (2017). The new battleground for marketing-led growth. McKinsey Quarterly. Downloaded October 15, 2017 from https://www.mckinsey.com/business-functions/marketing-and-sales/our-insights/thenew-battleground-for-marketing-led-growth.

\section{Summary}

The word digital is one of the most prominent in today's explanation of how we live. It is all around us. From products that are digital to a highest possible degree, to the digital management practices in operating different businesses, down to the wide discussions on benefits and shortcomings of the digital society. As some of the authors convincingly argue: after the agricultural revolution and the industrial revolution, the mankind is currently in the era of digital revolution. At the same time, the world is becoming increasingly global, which is boosting digitization to a large extent. Related to different aspects of globalization (that are briefly elaborated) the paper is focused on researching the possibilities that digitization is bringing within itself, which can be productive in a process of making (and empowering) global brands. The sharply increasing amount of information that are available to global consumers today through digital touchpoints (Facebook, Twitter, or product-evaluation platforms), is giving a great opportunities for certain categories of products/services to become globally branded. In a process of consumer decision journey, this is of great importance especially in a phase when consumers are considering an initial set of brands. However, at the same time, for globally oriented companies it poses a threat that is present in the form of a free interpretation (or misinterpretation) of the intended information value about their brands. 